\title{
Placental Stromal Dusty Mineralization
}

National Cancer Institute

\section{Source}

National Cancer Institute. Placental Stromal Dusty Mineralization. NCI Thesaurus. Code C118155.

The deposition of iron and/or calcium within the supporting tissues of the placenta. 